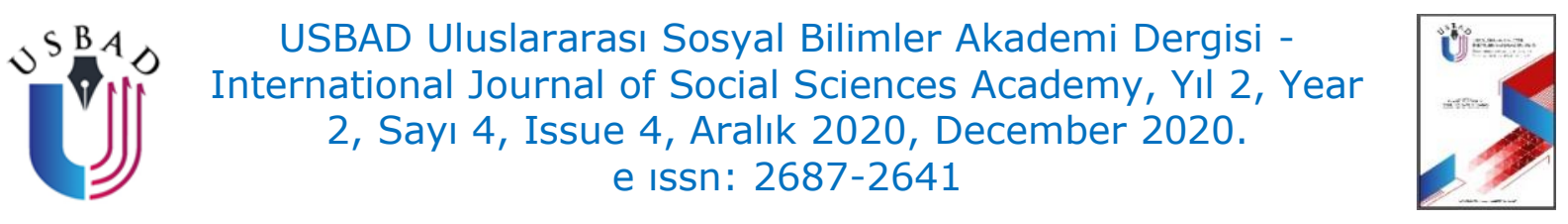

\title{
ÇAĞLARIN AKIŞINDA ANADOLU PİŞMİŞ TOPRAK KÜLTÜRÜ
}

CULTURE OF ANATOLIAN TERRA COTA IN THE FLOW OF THE AGES

\section{Serap ÜNAL}

Doç. Dr., Seramik ve Cam Bölümü, Süleyman Demirel Üniversitesi, Isparta/Türkiye.

Assoc. Prof. Dr., Ceramic and Glass Department, Süleyman Demirel University, Isparta/Turkey. serapunal@sdu.edu.tr

ORCID ID: 0000-0003-2407-1789

\section{Makale bilgisi | Article Information}

Doİ: 10.47994/usbad.762639

Makale Türü / Article Type: Araştırma Makalesi / Research Article

Geliş Tarihi / Date Received: 01.07.2020

Kabul Tarihi / Date Accepted: 16.09.2020

Yayın Tarihi / Date Published: 20.12.2020

Yayın Sezonu / Pub Date Season: Aralık / December

Bu Makaleye Atıf İçin / To Cite This Article: Ünal, S. (2020). Çağların Akışında Anadolu Pişmiş Toprak Kültürü. USBAD Uluslararası Sosyal Bilimler Akademi Dergisi 2(4), 927-956.

İntihal: Bu makale intihal.net yazılımınca taranmıştır. İntihal tespit edilmemiştir. Plagiarism: This article has been scanned by intihal.net. No plagiarism detected.

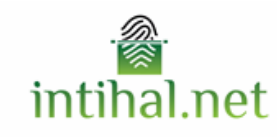

İletişim: Web: https://dergipark.org.tr/tr/pub/usbad mail: usbaddergi@gmail.com 
Öz: İnsanoğlu, tüm yaşamsallığında var oluşundan bugüne dek hayatını sürdürebilmek için çeşitli alet, araç-gereçlere gereksinim duymuş, gruplar/topluluklar içinde intiyacı olan ortam ve gereçleri doğadan üreterek ve kullanarak hayata tutunmuştur. Aynı zamanda insan sosyal bir varlıktır. En eski yerleşimlerin bize sundukları verilere göre, insanoğlu Nil Vadisi'nden Ön Asya Coğrafyasına ve Anadolu'da Paleolitik Dönemin başlarından itibaren ilk olarak taş yontarak alet edinmeye başladı. Sonrasında bu becerisini geliştirerek, tarımı, çanak çömleği, kadının önemini keşfetti, barınacağı evleri yaptı. Daha düzenli bir sosyal hayata geçti. İnsan çağlar boyu pişmiş toprak üretti ve halen günümüz endüstrisi de dahil üretmeye devam etmektedir. Tüm bunların yanı sıra, geçmişten günümüze verdiği zengin, sosyo kültürel betimsel malzeme ile çömlekçilik, binlerce yıllık geçmişi, üzerindeki bezeklerden formlarına, pişme derecelerine kadar birçok veriyi gerek arkeolojik gerekse etnografik olarak çok sayıda disiplinle birlikte bizlere sunmaktadır. Anadolu'nun bu kapsamda zengin bir kültür coğrafyası olduğunu düşündüğümüzde bu varlığın kültür varlıklarımızın önemli bir alanını oluşturduğu bir gerçektir.

Anahtar Kelimeler: Anadolu, Çanak, Çömlek, Çömlekçi Çarkı, Kadın, Kültürel Miras

Absrtact: Mankind has required various tools and tools in order to survive since its existence in all its vitality, and has clung to life by producing and using the environments and equipments needed in groups/communities from nature. At the same time, man is a social entity. According to the data provided by the oldest settlements, human beings began to obtain tools from the Nile Valley to the Early Asian Geography and from the beginning of the Paleolithic Period in Anatolia. Later, by developing this skill, he discovered agriculture, pottery, the importance of women, and built houses for him. He started a more regular social life. Man has produced terracotta for ages and still continues to produce including today's industry. In addition to all these, the rich, sociocultural descriptive material and pottery that it has given from the past to the present day presents us with a large number of disciplines both archaeological and ethnographic, from the decorations to the forms and the degrees of cooking. When we think that Anatolia is a rich cultural geography within this scope, it is a fact that this being constitutes an important area of our cultural assets.

Keywords: Anatolia, Pottery, Pottery, Pottery Wheel, Woman, Cultural Heritage

\section{GİRİ̧}

İnsanın var oluş mücadelesinde ihtiyaçlar hiyerarşisinin ilk basamağı/basamakları kapsamında, gerekli olan yardımcı aletler, var 
oluşla birlikte onun zekâsıyla yaratıldı. İnsan ilk olarak beslenmek, barınmak yani yaşama tutunmak için gereksinimi olan alet, araç ve gereçleri çağlar boyu geliştirerek üretti.

İnsanoğlunun Ön Asya coğrafyasında, Anadolu'da görüntü veren en eski varlığı ve yerleşmeleri, Paleolitik Dönemin başlarına kadar uzanır. Paleolitik Dönemin üç evresinde de (alt, orta, üst) insanlar mağaralarda barınıp, doğada rahatça elde edilebilen iri çakıl taşlarından kaba aletler yaparak yaşamlarını kolaylaştırıyorlardı. İnsan türünün, günümüzden 30-40 bin yıl önce "Homo sapiens neanderthalensis"den düşünen insan da dediğimiz "Homo sapiens sapiens" türüne dönüşümü ile taş aletler daha da geliştirilmiş, kemikten iğne gibi delici aletler kullanıma sokulmuştur. Ayrıca av hayvanları ve av sahnelerini betimleyen mağara resimleriyle düşünen insanın sanatsal yanı da ortaya çıkmıştır. Özellikle Hallan Çemi, Çayönü örneklerindeki Paleolitik Dönemin sonu (Epi-Paleolitik/Mezolitik) buluntular olan taştan kaplar, gelişmiş taş aletler, planlı taş konut örnekleri, daha gelişmiş farklı bir sosyal düzeni ve yeni bir çağın (Neolitik Çağ) gelişini işaret etmektedir.

Gordon Childe'ın deyişiyle devrim niteliğinde bir dönüşüm olan Neolitik Dönemde ise insan, buğday ve arpayı yani tarımı ve hayvancılığı keşfetmiş, toplayıcı ve avcı göçerlikten yerleşik düzene geçmiştir. Yerleşim yerlerini de mevsimsel zenginliklerin yoğun olduğu bölgelerden seçmiştir. Yeni bir sosyal dönem olarak kabul edilen Çanak Çömleksiz (Akeramik) Neolitik Çağ (M.Ö. 9600-7000), üretim ve örgütlü sosyal yaşamın başlangıç çağıdır. Seramiksiz Neolitik Çağ'ın güzel örneklerini veren yerleşmelerden Çatalhöyük ve Nevala Çori Höyüğünde özenli, 8-10 odalı taş duvarlı yapılar, kerpiç evler, kalkerden saklama kapları, takı süs eşyaları, çömlekçilik henüz olmamasına karşın balçıktan kadın figürinleri vb. buluntular, yanı sıra köy ve mahalle anlayışında konuşlanmalar, dönemsel gelişimin devamı olan bir sosyal yaşamın örneklerini sunmaktadır. Çanak Çömleksiz Neolitik'in ilk başlangıcından (Son Epi-Paleolitik) itibaren gelişmeye başlayan tarım, yerleşim ve inanç anlayışı, belli bir süre sonra daha işlevli bir toplum anlayışına geçişi zorlamış, daha sistemli yerleşim ve endüstri gereksinimini doğurmuştur.

Neolitik Dönemi ikiye bölen en önemli aşama, kilin ısıl yöntemle sertleştirilerek işlevsel olarak kullanımıdır. Çanak Çömlekli Neolitik Dönemde (M.Ö. yaklaşık 7000-6000) başlayan pişmiş toprak kültürü, toplulukların kültsel tören anlayışlarından, evi sosyal merkez haline getirmelerine kadar sosyal yaşantı düşününü ciddi bir biçimde 
etkilemiştir. $\mathrm{Bu}$ evrenin en önemli özelliklerinden biri de grup yaşantısından toplum yaşantısına geçiştir. Bununla birlikte, çömlek yapımının bu dönemde başladığını ve bilinçli bir şekilde aşama kaydettiğini biliyoruz (Childe, 2006: 36).

Bütün teknolojik gelişmelerde olduğu gibi, çanak çömlek yapımına başlanması da sosyal davranışların değişime uğramasına neden olmuş ve artık bu sosyal davranışlar insan hayatının temel taşları olan ev ve ocak etrafına daha çok odaklanmaya başlamıştır (Sagona, 2009: 77). Bu zaman diliminde çok farklı bir üretimsel anlayış ve bu üretim tarzının ivme verdiği yeni bir sosyal örgütlenme söz konusudur. Yeni sosyal yapıda artık kadın daha da önemlidir. Bu süreç, feminen özelliklerinden ve becerilerinden kaynaklı olarak kadını ön plana çıkarmıştır. Kadının yapacağı yemeği pişirmek ve erzak olarak saklamak için kaplara gereksinimi vardır. Kadının bu süreçte toprakla özdeşleştirilerek üretkenliğinin ve doğurganlığının göz önüne alınarak saygınlığının artması, kilden figürinleri yapılarak kült kapsamına alınmasına neden olmuştur.

İlk ve Orta Kalkolitik Dönemde (M.Ö. yaklaşık 6000-4000) ise, pişmiş toprak kaplar estetik ve işlevsellik açısından daha da geliştirilmiş, kap yüzeylerinde fark edilir biçimde değişiklikler gözlenmiştir. Bu dönem çanak çömleklerde açkı (perdah) uygulaması, çok renklilik ve bezemeler dikkat çekmektedir. Dönemsel araştırmalar yapan bilim insanlarınca dönemsel tarihleme açısından nispeten karmaşık bir süreç olarak addedilen bu dönemin/dönemlerin önemli yerleşmeleri, Güney Mezopotamya'dan uzanan Obeid ve Halaf kültürünün Anadolu'da devamı niteliğindeki yerleşmelerde önceki dönemin ilerisinde çanak çömlek örneklerine rastlarız. Kalkolitik Çağ'ın tüm evrelerini temsil eden yerleşmeler, Anadolu'nun hemen hemen tüm sathına yayılmıştır. Canhasan ve Hacılar çanak-çömlekleri döneminin en iyi örneklerini sunmaktadır.

İnsan topluluklarının Anadolu'da madeni çok öncesinde tanımalarına rağmen, süs eşyaları ve takı yapımı dışında madenin bilinçli kullanımı Orta Kalkolitik'te (yaklaşık M.Ö. 4000'ler den itibaren) başlamış Tunç Çağı'nda madencilik üst seviyede seyretmiştir. Bu çağın belki de en önemli olayı çömlekçi çarkının keşfidir. Çarklı çömlekçiliğe geçişle, günümüze kadar uzanan etno-arkeolojik değerleri artıran ilk endüstriyel üretim örneği ve tarzı meydana gelmiştir. Çömlekçi çarkı öylesine değerli bir buluştur ki Childe, çömlekçi çarkının devinimli tüm 
araçların ilham kaynağı olduğunu öne sürer. Bugün bile çömlekçi çarkının mı tekerlekten, tekerleğin mi çömlekçi çarkından esinlendiği, yani hangisinin önce keşfedildiği bilim insanları arasında tartışma konusudur. Çark devinimiyle oluşturulan çömlek yapımı, arkeoseramik buluntuların yanı sıra orijinal primitif teknolojisiyle birlikte eylemsel olarak bozulmadan Tunç Çağından günümüze kadar gelmiş ve Anadolu'da hala yaşamakta olan önemli bir kültürel miras öğesidir.

Çömlekçiliğin özellikle de çarklı çömlekçiliğin, devinimle işleyen tekerlek dahil tüm araç ve gereçlere de önderlik ettiği önemli bir toplumsal, sosyokültürel ve teknolojik gerçeklik olduğunu belirtmek gerekir. Diğer yandan günümüz pişmiş toprak endüstrisinin uzay araçlarının başlıklarına yerleşecek seviyelere gelişi de incelenmeye değer sosyo-ekonomik ve endüstriyel ayrı bir olgudur.

\section{1. ÇAĞLAR BOYU ÜRETİM SÜRECINNDE ANADOLU ÇÖMLEKÇİLİĞí}

Çağ kavramı, sosyal bilimciler ve özellikle de tarihçiler tarafından insanoğlunun belirli bir bölgede, belirli bir dönemde yasamış, geliştirmiş veya değiştirmiş olduğu maddi, kültürel, sosyal, ekonomik tüm sosyal olguları ve maddi kültürel değişim ve gelişim süreçlerini içine alır. Mesela, belirli bir coğrafyada yaşayan insanlar zaman içerisinde inşa ettikleri binalar ve yapı şekilleriyle önceki dönemlerden çok büyük farklılıklar göstermenin yanı sıra sosyolojik anlamda din, dil, kültür gibi alanlarda yepyeni bir farklılık, değişim veya gelişim gösterebilirler. Kullandıkları araç-gereçler yaşam tarzları düşünce şekilleri tamamen yepyeni bir forma dönüşebilir. Iste bu dönüşüm, değişim veya başkalaşım esasen yeni bir çağın başlangıcını işaret edebileceği gibi bir önceki çağın da sonunu gösterebilir. Dolayısıyla tarihçiler çağları ayırırlarken bu türden toplumu ilgilendiren siyasi ve sosyal olayları göz önünde bulundurarak toplumsal değişim ve gelişimi dikkate alarak çağ kavramını kullanmışlardır. Ancak hemen belirtelim ki çağ kavramı aynı anda tüm dünya için geçerli değildir ( $\mathrm{Avcl}, 2013$ : 7).

Tüm çağların hemen her evresinin dolu dolu yaşandığı Anadolu coğrafyası sosyal, kültürel ve teknolojik gelişmelerin en iyi belgelerini veren bir coğrafyadır. Bu bağlamda arkeolojinin en iyi belgesi sayılan çanak çömlek buluntular, geçmişi bize bilimsel olarak taşıyan ve betimleyen sosyo-kültürel değeri yüksek bir veri alanıdır. 


\subsection{Paleolitik, Epi-Paleolitik Dönemler (M.ö. 1.000.000- 9600)}

Paleolitik Döneme Mezolitik Dönemle (Epi-Paleolitik) birlikte bakacak olursak; İnsanlık tarihinin en uzun dönemi kabul edilen bu süreç alt, orta ve üst olmak üzere üç döneme ayrılır.

Alet kullanan ilk insanların, Afrika'da ortaya çıkışından yaklaşık M.Ö. 11.000'de Buzul Çağı́nın gerilemesine kadar olan süreyi kapsayan Paleolitik Çağ, Avrupa'da yüz yılı aşkın süredir ilgi uyandırmasına karşın Türkiye'de Paleolitik Çağ araştırmaları göreli olarak daha yeni bir alandır. Bunun nedenlerinden biri, genellikle daha sonraki dönemlere ait tabakalarla örtülmüş olan ve kısa süreli insan etkilerini yansıtan en eski Paleolitik buluntu yerlerinin saptanmasıdır (Sagona vd., 2009: 9).

$\mathrm{Bu}$ dönemin Anadolu'daki belli başlı önemli buluntu yerleri, Yarımburgaz, Karain, Beldibi, Kumbucağı, Belbaşı ve Öküzini gibi çok uzun süre iskân edilmiş ya da yöntemli bir biçimde araştırılmış bu mağaraların yanında, Anadolu'da bu döneme ilişkin başlıca mağara ve kaya altı sığınağı türünde yerleşmelere, Kars yakınlarında Camuşlu, Elazığ yakınlarında Küllününini, Gaziantep'te İkizini ve Dülük vadisindeki Şarklı Mağara, Antakya'da Kanal, Üçağızlı, Tıkalı ve Merdivenli, Diyarbakır'da Malikli, Isparta'da Kapalıin, Antalya yakınlarında da Kızılin, Gavurini ve Çarkini'nde rastlanmıştır (Sevin, 1999: 19). Bu yerlerin dışında daha birçok yer bu döneme ait buluntular vermektedir. Paleolitik Dönemin Anadolu'da rastlanan en eski yeri Yarımburgaz'dır.

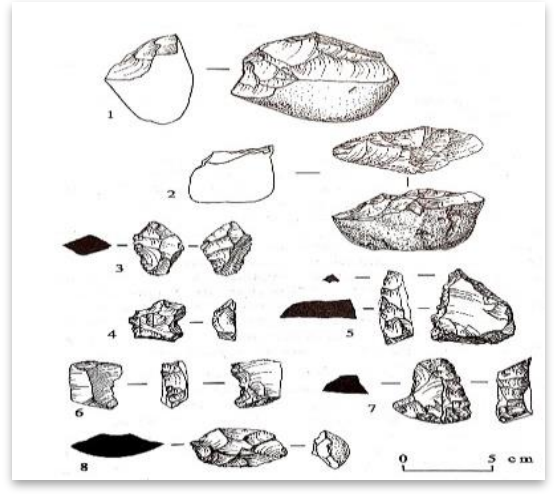

Görsel 1: Yarımburgaz Mağarası Paleolitik'e ait yontma taş aletler (Sagona vd., 2009: 14)

Arkeologlara göre, insanın dünyada türeyişini yaptığı aletler belirler. İnsan, besin ve barınak edinmek için, fizyolojik donanımındaki 
eksikliklerini aletlerle tamamlar. Beyninin ve sinir sisteminin sağladığı el ve göz bağlantısının ince dengesiyle aletler yapar. İlk aletler anlaşılan tahta, kemik ya da taş parçalarıydı, bu parçalar kırılıp yontularak ele uygun biçime getirilir, az çok sivriltilirdi. Tahtadan yapılanlar çoktan yok olmuşlardır. İlk taş aletler de doğal olarak (don ya da sıcaklar nedeniyle veya ırmak kenarlarında yuvarlanarak) parçalananlardan ayırt edilememiştir. Oysa ilk buz çağının da öncesinden beceriyle, yontucu, sıyırıcl, kesici aletler olarak biçimlendirilmiş olan sert taş parçalarını arkeologlar ayırt edebilmişlerdir. Bu tür aletlerin insan tarafından biçimlendirilmiş olması bugüne dek tartışılsa da bilginlerin çoğunluğunca kabul edilir (Childe, 2006: 36).

Anadolu yarımadasındaki en eski yerleşme izleri Alt Paleolitik Çağ'dan (Eski Taş Devri) kalmadır. Günümüzden 400.000 yıl önce başlamış olan bu zamanda yarımadada Afrika kökenli Homo erectus (dik yürüyen insan) türü insanlar yaşamaktaydı. Bu evre insanları gerek beyin kapasitelerinin gelişmesine gerek kültür birikiminin artmasına paralel olarak, basit yongalama ve işleme teknikleriyle, avlanmak, yabani hayvanlardan korunmak ve günlük işlerinde kullanmak üzere çeşitli yontma taş aletler üretmişlerdir (Sevin, 1999: 15-16).

Alt Paleolitik Dönemin Anadolu'da bilinen en eski yerleri olarak öne çıkan Yarımburgaz ve hemen sonrasına ait Karain Mağarasında insanoğlunun ilk aletleri olarak bilinen yüzlerce yongalanmış taşlar bulunmuştur.

Yarımburgaz'da bulunan taş aletler, ana hammadde olan çakmaktaşının yanı sıra, kuvars ve kuvarsitten yapılmıştır. Karain mağarası ise geniş bir karstik sistemin parçasıdır ve taş alet yapımına uygun, çoğunlukla radyolarit çakıllar ve yumrular halinde hammaddenin bolca bulunduğu bir coğrafyada yer almaktadır (Sagona vd., 2009: 13).

Orta Paleolitik Evrede yine en iyi tabakalanma olarak gösterilen Karain Mağarasında, önceki dönemin devamı niteliğinde avlanma amaçlı yongalı taş tipi yaygındır. Üst Paleolitik'te ise aynı amaçılı aletler biraz daha gelişmiştir. Nitelik ve nicelik yönünden Üst Paleolitik'te fazlalaşan ön kazıyıcılar, tas kalemler, tas delgiler ve sırtlı bıçaklar bu endüstrinin alet grubunu tamamlamaktadır.

Bu dönemde yongalanmış taş üretimine ilaveten kemik el aletleri ve deniz kabuklarından süs eşyaları da görüntü vermeye başlar. 
Özellikle Epi-Paleolitik (Mezolitik) Dönemin sonlarına doğru, iki önemli yer olan Hallan Çemi ve Çayönü bize döneminin en gelişmiş örneklerini verir. Taş kap yapımı, yongalanmış taşları incelterek, küçülterek daha da kullanışlı hale getirdikleri mikrolitler, kişisel süs eşyaları, takılar, boyalı kaya resimleri ile sembolizm anlayışında sanat ve en önemlisi daha düzenli, planlı mekân seçimleri ve farklı ritüelleri olan yeni bir toplumsal düzen; artık tarımla, üretimle, yerleşik toplumsal yaşamla ve ardından çanak çömlekle aydınlanacak yepyeni bir dönemin yani Neolitik Çağın habercisidir.

\section{2. İnsanoğlunun İlk Devrimi, Neolitik Dönem (M.Ö. Yaklaşık 9600-4000)}

İnsanlık, zorluklar içinde sadece yaşama tutunmak erkiyle, biriktirdiği edinimi ve geliştirdiği zihinsel yapısıyla en uzun ve zorlu dönemlerini geride bırakarak, devrim niteliğinde bir çağ açtı. Buzul Çağının tamamen sona ermesi ile birlikte, çevresel koşulların da yardımıyla, bu dönemde modern insanın başlangıcı ortaya çıktı. Azınlıkta da olsa besin elde edilişinin, toplayıcılıktan üretime geçilmesini devrim olarak görmeyen araştırmacılar olmasına karşın Childe bu dönüşümü devrim olarak görür. Zira dönemin üretim anlayışı, insanın yerleşim, barınma ve kültürel bağlamda sosyolojik düşününü de temelli değiştirmiştir. Elbette her yeni oluşum öncesi safhalar ve kademeli geçişler mutlaka vardır ancak bu değişimin modern anlamda insanı insan yapan sosyal ve üretsel yapılanmada yaptığı köklü ve keskin aşama inkâr edilemeyecek kadar önemlidir. Kısaca Neolitik Çağ, ilkel topluluktan uygar topluma geçiş çağıdır.

İnsan, bu dönemde toprağı daha iyi tanıdı, toprağın ona nasıl fazla besin vereceğini, bitkilerin kültüre alınmasını öğrendi ve kendini besleyecek hayvanları evcilleştirdi. Ekonomik gelişmelerle, mahalle, köy gibi sistemli yerleşimler oluşturarak, kentsel yaşamın ilk adımları bu dönemde atıldı. Yine çekirdek ve geniş aile düzeninde bir sosyal hayata geçildiğini, Neolitik yerleşmelerdeki aile yapısına göre boyutlandırılmış evlerden anlıyoruz. Bu dönemin diğer önemli bir özelliği de kadının ön plana çıkmasıdır. Kadının doğurganlığının, toprağın bereketi ile özdeşleştirilmesi, bununla birlikte besleme yeteneği, pişmiş toprak kap yapımı vb. özellikleriyle kısaca her konuda üretkenliği onu tanrıçalığa kadar yükseltmiştir. Önceki avcılık dönemlerinde av silahlarının erkeğin elinde olmasıyla erkeğin önde olduğu yapının, yeni dönemde besin üretiminin ve yapımının kadına geçmesiyle artık hâkim unsur kadındır. İlk sanat yapıtları, hayvan 
betimli kazımalar ve Ana Tanrıça figürinleri bu evrede yoğun olarak ortaya çıkmıştır.

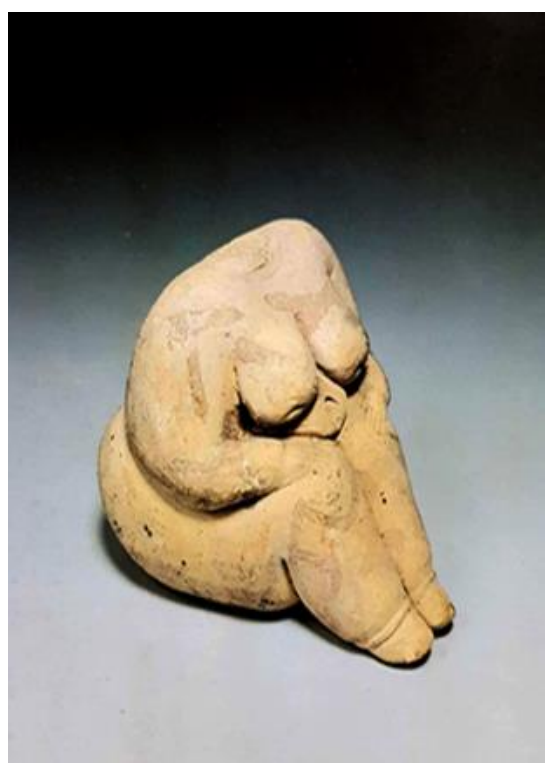

Görsel 2: Oturan Ana Tanrıça Heykelciği

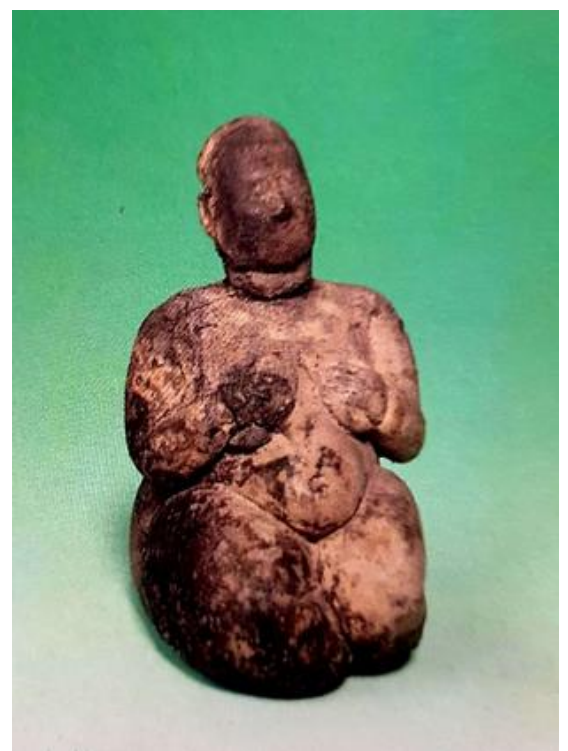

Görsel 3: Oturan Ana Tanrıça Heykelciği, Çatalhöyük, M.Ö. 6. Bin Yıl İlk Yarısı (Kulaçoğlu, 1992: 24)

Bu türün en ilginç örnekleri küçük kadın heykelcikleridir. Bu kadınlar hamile oldukları gibi kadınsı özellikleri de olağanüstü vurgulanmıştır. Bu "Venüs" ya da "Ana tanrıça" heykelciklerinin doğanın büyük güçleri olan bereketi ve yaşamın doğuşunu simgeledikleri sanılmaktadır (Braidwood, 1995: 115).

Neolitik köyde erkeklerin hayvan, kadınların bitki yetiştirmekle uğraşmaları biçiminde bir is bölümü görülür. Ancak, kadınların tahıl üretiminin ve hayvan yetiştiriciliğinin ev ekonomisi içindeki uzantıları olan öğütme, pişirme ve yoğun tarım mevsimleri dışında çömlek kaplar yapma, örme, dokuma gibi işlerle de uğraşmalarına bakarak; köylerde, neolitik ekonominin daha çok kadınların çalışmalarına dayandığı söylenebilir (Şenel, 1982: 159-160). Bundan ötürü, kadınların ekonomik alanda önemli bir rol oynamaları da kadınların toplumsal saygınlığını büyük ölçüde artırmasına ciddi bir etken olmuş olabilir. Childe'ye göre; Neolitik kalıntılar içinde, totemleri temsil etmeleri olası hayvan heykelcikleri yanında, çok sayıda kadın heykelciği ile karşılaşmamız kadının saygınlığının artışının göstergelerinden biridir. Bir başkası, soy zincirinin anaya göre hesaplanması olmalı. Çağdaş ilkellerden sağlanan dolaylı kanıtlar gösteriyor ki, salt tarımla uğraşan toplumlarda, kadının kolektif ekonomiye katkıları sayesinde, akrabalık 
doğal olarak kadının soy zincirine (matrilineal) dayanır ve "ana hakkı" egemendir.

İnsanlık tarihinin en eski maddi kültür kalıntıları arasında yer alan pişmiş toprak hayvan ve insan figürleri, insanların çok eski çağlardan beri kili biçimlendirip pişirerek sertleştirmeyi bildiklerine işaret etmektedir. Bu çağlarda besinini avcılık ve toplayıcılıkla elde eden insanların pişmiş topraktan kap üretmedikleri, kaplarını ya taştan oyularak ya da sepet, tahta, deri gibi zamanla yok olan maddelerden ürettikleri anlaşılmaktadır. "Seramiksiz Neolitik Çağa" tarihlenen yerleşimlerde sepet izlerini taşıyan kil parçacıklarının ele geçmesi, ilk denemelerin sepetlere kil sıvanarak başladığını göstermekte, güneşte kurutulmuş kil kap parçacıkları da seramik üretimine geçiş evresini yansıtmaktadır (Ökse, 2015: 7).

Çanak Çömleksiz Neolitik Dönemin en önemli yerleri Nevali Çori, Çayönü, Hallan Çemi gibi yerleşmelerdir. Ancak, Güneydoğu Anadolu'da Şanlıurfa ilinin kuzey batısında, Birecik ilçesinde bulunan Mezraa Teleilat, Neolitik Dönemin çanak çömleksiz evreden, çanak çömlekli evreye geçişini kapsayan, açkılı (perdahlı) çömlek parçalarıyla, figürinleriyle ve farklı yapılaşmasıyla bu geçişi betimleyen ilginç ören yeridir.

\section{3. Çanak Çömlekli Neolitik Dönem (M.Ö. Yaklaşık 7000- 6000)}

Çanak Çömleksiz Neolitik Dönem (M.Ö. 9600-7000), çanak çömleğin devreye girmesiyle geride kaldı. Neolitik Dönemi ikiye ayıran, en önemli olay çanak çömleğin insan yaşamına doğrudan bilinçli olarak girmesidir.

Tahılın hazırlanması ve depolanması, sıcağa dayanan ve su tutabilen kapların önemini artırmış olmalı. Neolitik toplumların ortak özelliğinin kap kaçak yapımı olduğu anlaşılmaktadır (Bu kaplar Filistinli Natfiyan'lar tarafından kullanılmaktaydı). Gerçekten de toprak kap kaçak, besin üreten ekonominin oluşumundan daha önce bulunmuş olabilir. Belki de su geçirmemesi için kille sıvalı bir sepetin rastlantıyla yanması sonucu bulunmuştur. Kenya'da Eski Taş Çağından olduğu sanılan küçük çömlek parçaları bu olasılığı düşündürmektedir. Büyük çapta çömlek yapımı ancak Neolitik çağda başlamıştır. Neolitik yerleşme alanları genellikle kırık çömlek parçalarıyla bezelidir (Childe, 2006: 60). 
Kadının ürettiği çanak çömlekle, hazırladığı yiyecekleri pişirip yine, kendi yaptığı pişmiş toprak kaplarda erzak olarak saklayarak besin güvencesini sağlaması, tarımla başlayan Çanak Çömleksiz Neolitik Dönemde üreterek kazandığı saygınlığını daha da artırdı.

Tüm çağlarda olduğu gibi Anadolu, Çanak Çömlekli Neolitik Çağ'ın da zenginidir. Bu döneme ait yüzlerce ören yeri mevcut olup, çalışmaları yapılan birçok Neolitik Yerleşimin hemen hepsinde seramik buluntular mevcuttur. Bu dönemde çanak çömlek üretiminin başlamasıyla insan yaşamında yine köklü denecek sosyal değişiklikler başlamış, ev ve ocak başında bir aile yaşantısı şekillenirken, farklı bir inanç anlayışını betimleyen yeni bir yapılanma da yine bu dönemde gözlenmektedir.

Dini etkinlikler artık büyük tapınakların içinde ve çevresinde değil, evlerde yoğunlaşmıştır. Dinsel imgeler değişime uğramıştır. Torosların kuzeyindeki buluntu yerlerinde bazen canlı, bazen yumuşatılmış olan yeni ikonografik öğeler belirlenebilmiştir. Bunların en dikkat çekicileri, belirgin kadın figürinleri ve çağrışım gücü yüksek duvar resimleridir. Başka örneklerde ise betimlemeler daha sadedir ve günlük eşyalarda görülmektedir. Kullanılan sembolizm ne olursa olsun, kutsal alan anlayışı ve ruhlar dünyasıyla iletişimin nitelikleri bu dönemde değişime uğramıştır (Sagona vd., 2009: 77-78).

Plastik bir malzeme olan kilin kullanımı, Neolitik Dönem genelinde çok amaçlı olarak kullanılmıştır. Kilin yapı yalıtımlarından, ocak, fırın, ambar raflarından, figürinlere, kap kacak yapımına kadar birçok alanda kullanıldığını biliyoruz. Bu dönemin Anadolu'da en öne çıkan merkezleri, Çatalhöyük, Çayönü ve diğer dönemlere/dönemlerden taşabilen merkezler olarak da Hacılar, Kuruçay ve Hallan Çemi'yi sayabiliriz. En yoğun araştırılan ve bilinen yerleşmelerden biri Çatalhöyük'tür. Buradaki sosyal ve kült anlayışla Neolitik değişimi rahatlıkla gözlemleyebiliriz.

Otuz iki hektarlık alanıyla, Çatalhöyük hiç kuşkusuz Yakın Doğu'daki bilinen en büyük Neolitik yerleşmedir, fakat henüz bu alanın yalnızca bir hektarını kaplayan kutsal alan kazılmıştır. Yapılan radyo karbon tarihlemesine göre, yaklaşık M.Ö. 6500'den M.Ö. 5650 yılına dek bin yıla yakın bir süreyi kapsayan art arda on iki yapı katı (O-X) düzenli ve kesintisiz bir kültür gelişimini yansıtır. M.Ö. 5900 yıllarına tarihlenen VI A tabakasına sonunda, teknik yönden çok gelişen çanak çömleğin benimsendiği görülür. Çatalhöyük'te yalnızca V-O 
tabakalarında çanak çömlek üretiliyordu. Fakat o zaman bile, tahta ve hasır kapların kalıplaşmış biçimleri yerleşmenin sonuna dek toprak kapların biçimlerini etkilemiştir. Bunlar koyu perdahlanmış kaplardır, fakat Çatalhöyük'te koyu renk çoğunlukla yemek pişirmekte kullanılan kaplarla sınırlıdır ve V. tabakadan başlayarak devetüyü renkli kaplar ortaya çıkar (X. tabakadan başlayarak kırmızı çanak çömlek görülür). IV. tabakada çekici renklerle yapılmış benekler yaygındır ve ilk kırmızı boyalı çizgiler III ve II. tabakalarda görülürse de oldukça enderdir (Melart, 1988: 75-79).

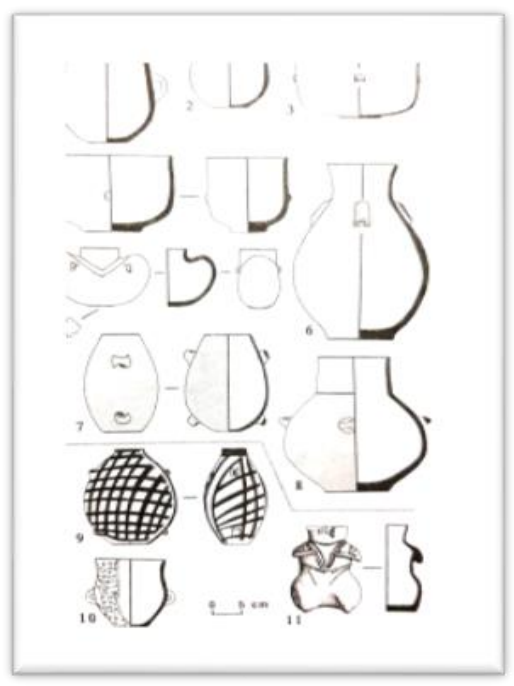

Görsel 4: Batı Anadolu'dan Neolitik Çanak-Çömlek. 1,2,10: Höyücek; 3, 7: Hacılar;

5, 6: Höyücek; 4, 8: Kuyucak; 11: Hacılar; 10: Ulucak (Sagona vd., 2009: 10)

Çatalhöyük seramiğinin diğer bir dikkat çeken yanı da, taş idollerin yanı sıra özellikle pişmiş toprak figürinlerdir (seramik figürinler taştan yapılanlardan daha fazladır). Çatalhöyük kesintisiz bir kült süreci yaşamıştır. Çeşitli hayvan ve insan figürinleri arasında en önemli parçalar Ana Tanrıça idollerine aittir. Ayrıca güç ve kötülüklerden korunma amaçlı duvarlara resmedilmiş/raptedilmiş iki ve üç boyutlu güçlü hayvan ve boğa figürleri de dikkat çekicidir.

Çatalhöyük görüldüğü gibi Ana Tanrıça inancıyla ilgili sayılabilecek bol malzeme vermiştir. Heykelcikler, duvar resimleri ve kabartmalar doğum yapmakta olan ya da küçük çocukları taşıyan kadınları göstermektedir. Bunların birçoğu içerik ve süslemeleri nedeniyle dinsel amaçlı kullanıldıkları düşünülen odaların içinde bulunmuştur. Üstelik bu tür malzeme kısıtlı bir ya da iki bölge içinde diğerlerinden soyutlanmamış olup, buluntu yerinin katlarının her tarafında bulunmuştur. Burayı ilk kazan kişi olan James Mellaart, kadın heykelcikleriyle kabartmalarını hemen Yunan ve Roma Cybelesi'nin 
prehistorik öncülünün Anadolu'nun Ana Tanrıçası'nın betimleri olarak yorumlamış, popüler ve bilimsel yazında birçok kişi bu konuda onun izinde gitmiştir (Roller, 2013: 53). Mellaart'ın Çatalhöyük'te ileri sürdüğü Ana Tanrıça kültü, azınlıkta da olsa bazı bilim insanlarınca eleştirilmiş ancak bu yerleşmeye yıllarını vermiş bir bilim insanı olarak Mellaart, bulguları ve yorumlarıyla geniş kabul görmüştür. Zaten çanak çömlekli süreçte yoğunlaşan kültsel anlayışın, Ana Tanrıça kültü örnekleri pişmiş toprak idollerde çoğalmış olması da dönemin ruhuna uygundur.

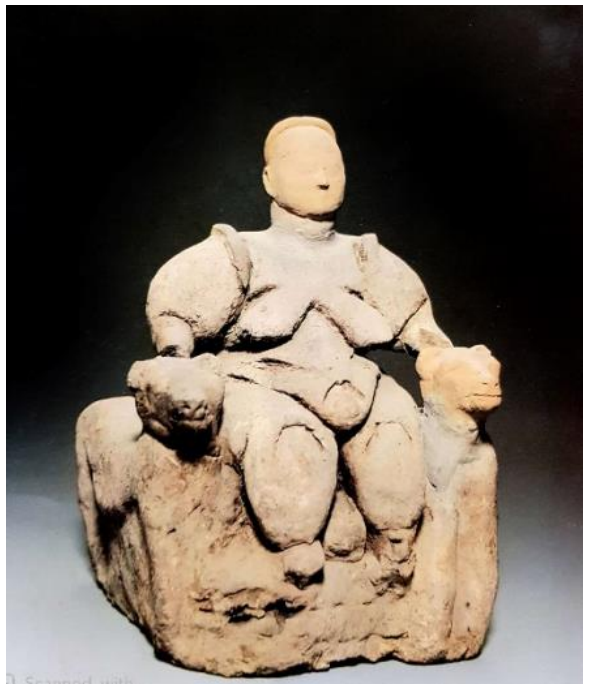

Görsel 5: Ana Tanrıça Heykelciği, Çatalhöyük, M.Ö. 6. Bin Yılın İlk Yarısı (Kulaçoğlu, 1992: 24)

$\mathrm{Bu}$ sonuçlara, eski toplumlarda kadının rolünden hareketle varmaktayız. Bu rol erkeklerin veya avcıların rolü gibi pragmatik değil, tersine yaratıcı türde tüm yaşam sürecini kapsayan farklı bir roldü. Ya da diğer bir anlatımla şöyle denilebilir; Erkeklik bilinci amaca yönelikti, kadınlık bilinci ise evrensel ve geneldi (Uhlig, 2007: 57). Ayrıca, kadının doğurganlığının, üretkenliğinin, bereket üreten toprakla özdeşleştirilmesi öne çıkan bir faktördü. İnsan, mağara duvarlarında başlattığı sanatsal becerilerini önce sosyal hayatında yaşadığı planlı ev çeperlerinde ve sonra da pişmiş toprakla ivme kazanan sanatını, ürettiği çanak çömlek üzerinde gösteren Neolitik Çağ insanı artık yeni bir çağa hazırdı.

\section{4. Kalkolitik Çağ (M.Ö. Yaklaşık 6000-4000) ve Bezekli Çömlekler}

İlk Kalkolitik, belirsizliklerine karşın önemli bir dönemdir. "Tarım Devrimi" ile "kent devrimi" arasında kalan bu dönem gerçekten de M.Ö. 
4. bin yılda gerçekleşen çoğu karmaşık bir dizi sosyo-politik değişimin çıkış noktası olması açısından önemli olduğu kadar, tanımlanması da zor bir dönemdir. M.Ö. yaklaşık 6000'lerde Son Neolitik'ten İlk Kalkolitik'e geçiş sürecinde Anadolu'nun büyük bir kısmında değişiklik görülmektedir; ancak bu değişim geleneklerde belirgin bir kırılmayı işaret edecek kadar yeterli değildir. Gerçekten de ilk Kalkolitik kültürlerin belirleyici birçok özelliği esasen Neolitik'tir (Sagona vd., 2009: 116). Neolitik'le başlayan devamlı yerleşim ve onun tetiklediği toplumsal gelişmeler Erken Kalkolitik'te devam etmektedir. Toplumların giderek göreceli olarak zenginleşmesi o toplumların yaşam biçimine henüz geçmemiş göçebe insan gruplarının yağma hırslarının artmasına da kuşkusuz neden olmuştu. Yerleşikler için bu tehlike, toplumsal organizasyona geçilmesi, yani toplumun yönetilmesi için güçlü kişilerin veya kadroların ortaya çıkmış olmasıyla çözülmüş olmalıdır. Aynı sorun, yerleşmelerin korunması için mimari önlemler alınmasını, bir savunma sistemine sahip olunmasını da yaygınlaştırmıştır (Duru, 2008: 8). Kalkolitik'in ilk safhasından itibaren kültürel açıdan bakıldığında, sanatsal olarak dikkat çeken gelişme, çanak çömlek kaplar üzerindeki bezemelerin özenli şeklide artmasıdır.

Kalkolitik Dönemde, Anadolu'nun yaşanmışlığı en dolu bölgelerinden özellikle Göller Yöresi'ndeki pişmiş toprak buluntular sanatsal anlamda bir gelişmeyi gösterir. Bu yörede öne çıkan dönemin önemli yerleşmeleri, Hacılar, Kuruçay, Bademağacı ve Höyücek'tir.

Kalkolitik Çağ'ın Anadolu'daki en parlak merkezi Burdur yakınındaki James Mellaart tarafından kazılan Hacılar Yerleşmesidir. Burada bulunan boyalı anıtsal vazolar özellikle anılmaya değerdir. Pişmiş toprak kaplardan, M.Ö. 6. binin ortalarında, özellikle Çatalhöyük'te, Hacılar'da yapılanlar çok başarılı olup, insanlığın seramik konusunda ortaya koyduğu ilk sanat yaratılarıdır (Akurgal, 1998: 8).

Çanak çömlekler çok renkli ve tek renkli olmak üzere iki büyük kümeye ayrılır. Biçimleri açısından birbirlerinden farklı olmayan bu iki türden ilk gruptakiler, iyi açkılı açık renk zeminine koyu kırmızı ya da kahverengi bezemeleriyle yalnızca Anadolu'nun değil tüm Yakın Doğu ve Ege Dünyası'nın en özgün çanak çömlekleri arasındadır (Sevin, 1999: 67).

Hacılar'da ortaya çıkan diğer bir seramik kültürü de pişmiş toprak figürinlerdir. Bu idoller, önceki dönemlere göre sayıca çoğalmış ancak 
Çatalhöyük'tekiler gibi çoklu (hayvanlı, çocuklu) değil, daha sade ve tekil sembolize edilmiş tanrıça figürinleri halindedir. Her ne karmaşık bir çağ da olsa, bu dönemin seramik kaplarıyla öne çıkan yerleşmesi, Hacılar'dır. Tek renkli (monokrom) ve çok renkli (polikrom) Hacılar çömleklerindeki estetik anlayış gerek bezemelerde ve gerekse formlarda ön plana çıkar.
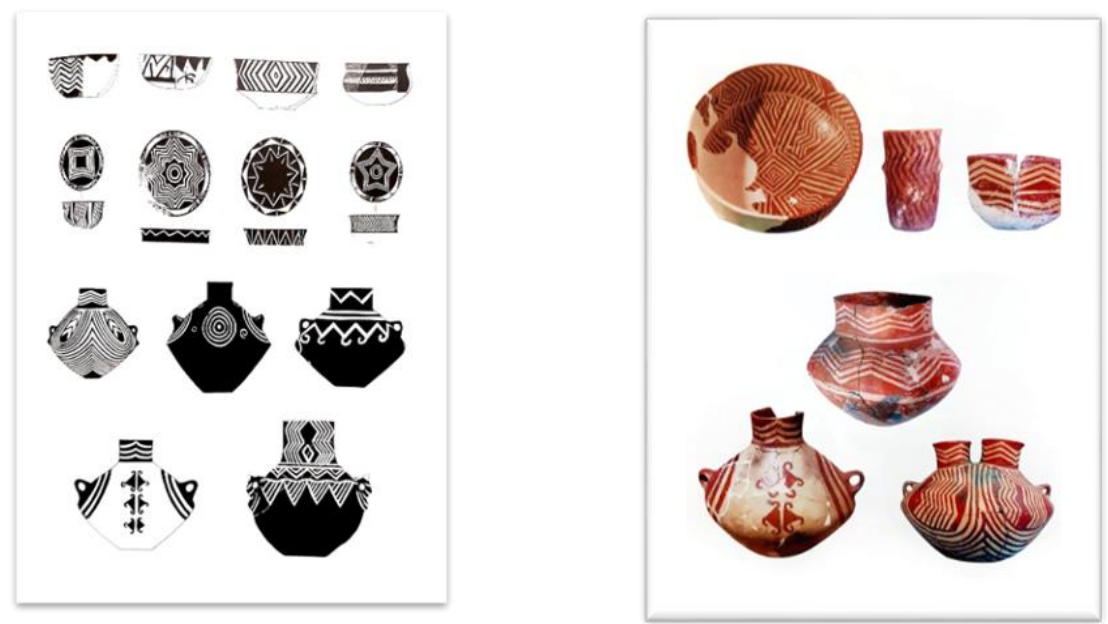

Görsel 6, 7: Hacılar I Çömlekleri (Duru, 2008: 8, 86)

Kalkolitik Dönemin Göller Bölgesi'ndeki başka bir temsilcisi de Kuruçay olup kendisinden $8 \mathrm{~km}$. uzaklıktaki Hacılar'dan pek çok yönüyle ayrılır. En önemli farklılık Hacılar'daki bitişik düzene karşılık buradaki evlerin bağımsız birimler halinde düzenlenmiş oluşudur (Sevin, 1999: 68).

Kuruçay GKÇ yapı katlarının çanak çömleği, genellikle tabak, çanak, bardak ve maşrapa gibi yeme içmede veya benzeri işlerde kullanılmak üzere yapılmış, çoğunluk küçük ya da orta boyda ve özenli sofra kapları ile depolama, taşıma ve mutfak işleri için fazla özen gösterilmeden yapılmış iri boyda kaba mallar olarak iki büyük gruba ayrılabilir (Duru, 1996: 25).

\section{5. Maden ve Çömlekçi Çarkı, Son Kalkolitik ve Tunç Çağı (M.Ö. Yaklaşık 4000-2000)}

Neolitik Dönem'de başlayan Anadolu'nun ileri hamlesi, İlk ve Orta Kalkolitik'te sosyo-kültürel ve ekonomik olarak şekillenmiş, Son Kalkolitik'te ise Anadolu kültürleri, Uruk'tan itibaren Anadolu'ya Fırat kıyılarından uzanan kültürlerle, buluşarak Arslantepe'de adeta bir 
merkez oluşturmuş ve güçlenerek Anadolu içlerine ve Erzurum Karaz kültürü olarak Transkafkasya'ya yayılımını sürdürmüştür.

Kronolojiyle ilgili her konuda olduğu gibi burada da zaman süreci ve terimler konusunda çeşitli yaklaşımlar varsa da Anadolu'da Son Kalkolitik yaklaşık olarak M.Ö. 4. bin yıla (M.Ö. 4000-3100) tarihlendirilmektedir. Bununla birlikte bu dönemin. İlk Tunç Çağı'ndaki edinimler ve bağlantıların öncülü olan kültürel gelişmelerde dönüm noktası olduğu genel olarak kabul edilmektedir. Bu nedenle iki dönemi bir arada görmek uygun olacaktır. Son Kalkolitik in ayırt edici özelliği, hammadde arayışını hızlandıran zenginliğe ve konumlarını sergilemek için doyumsuz bir isteğe sahip insanların kontrolündeki yeni sosyoekonomik yapıların ortaya çıkışıdır. Otoritelerinin en büyük göstergesi olan yeni teknolojilere ve lüks eşyalara olan gereksinim, kültürel sınırların genişlemesine neden olmuştur. Bu durum özellikle Yakındoğu ve Anadolu kültür bölgelerinin çakıştığı Fırat Vadisinde belirgin olmuştur. Doğulu toplumlar Kalkolitik Çağ boyunca, Toroslar'a ve sonunda Orta Anadolu Bölgesi'nin eşiğine dek ilerlemişlerdir. Ticaret sayesinde ivme kazanan kültürler arası bu ilişkiler, daha sonraki çağlarda artmış ve İlk Tunç Çağının sonunda Anadolu'nun büyük bir kısmı Ege'den Suriye Mezopotamya'sına kadar uzanan bir ağın parçası haline gelmiştir (Sagona vd., 2009: 131).

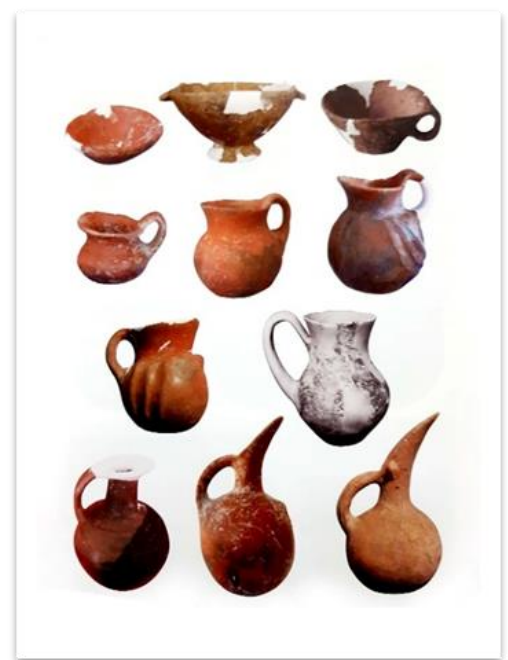

Görsel 8: Bademağacı İlk Tunç Çağı II Çömlekleri (Duru, 2008: 165)

Son Kalkolitik'te kültürlerin Anadolu'daki en önemli merkezlerinden biri belki de en önemlisi Arslantepe'dir. Son Kalkolitik ve Tunç Çağının bu önemli merkezi, aynı zamanda ilk devlet yapılanması örneğini de vermektedir. Kamulaşmanın, ticaretin ve teknolojinin buradaki gelişimi de dikkat çekicidir. 
Anadolu'nun Son Kalkolitik dönemi, Uruk yayılımı olarak bilinen olgunun ışığında incelenmektedir. Bu yayılım, çanak çömlek, resimli bezekler, mimari, pişmiş toprak duvar çivileri ile mühürler, mühür baskıları ve çivi yazısının öncülü olan tabletleri içeren idari araçlar gibi maddi kültür öğeleriyle belirlenmektedir (Sagona vd., 2009: 131). Bu dönemin önemli olaylarından biri de Uruk'tan Anadolu'ya giren çömlekçi çarkının kullanımının başlamasıyla Anadolu çömlekçiliğinde önemli bir aşama yapılmıştır. Yine bu döneme ait kabartmalı, kazımalı, kırmızı siyah astarlı çok renkli kaplar ve yüksek ayaklı törenlerde kullanıldığı düşünülen kaplar ön plandadır.

Bu çağın teknolojik olarak tarihte ilk endüstriyel üretim sayılabilen buluşu, çömlekçi çarkıdır. Tekerleğin bulunuşuyla benzer döneme geldiği için hangisinin önce bulunduğu tartışma konusudur. Son Kalkolitik ve İlk Tunç Çağı (İTÇ) dönemlerinde Uruk'ta bulunan çömlekçi çarkının bulunuş tarihi hakkında net bir bilgi olmamakla birlikte, Prof. Güngör Güner'in anlatımıyla; Ali Rıza Yalgın'ın L. Woolley'in Ur kazılarından kaynaklı olarak yazdığı, Türk Tarih Arkeologya ve Etnografya dergisinden alıntıladığı ifadeyle,

"M.Ö. 3500 yılına ait olduğu saptanan Uruk'ta ilk çömlekçi çarkına, dolayısıyla çarklı çömlekçiliğe rastlanmıştır. Anadolu'da ilk çarklı çömlekçiliğe ait bulgulara M.Ö. 3000-2000 yılları arasında ilk kez Kayseri dolaylarında Alişar'da, Boğazköy'de ve Truva'da rastlanıyor" (Güner, 1988: 10).

Çömlekçi tornasını da görünüşte, arabaya bağlamak lazımdır. Erek, Anav ve Mohenjo-daro'da bu aynı icadın iki tasviri belki de aynı zamanda görülmüştür. Fakat Girit'te ve kuzey Suriye'de tekerlekli araba intimal ki çömlekçi tornasından önce benimsenmiştir. Halbuki Mısır'da iki icat arasındaki bu münasebet ters idi (Childe, 1971: 232).

$\mathrm{Bu}$ dönemin en önemli buluşu sayılan çömlekçi çarkı, aynı zamanda sosyal bir dönüşüme de neden olmuş, çarklı çömlekçilik öncesi pişmiş toprak yapımında öne çıkan kadının hükümranlığı azalıp, çarkta çömlek yapımı, ilk başlarda çarkın malzemesinin belki de ağır olması nedeniyle erkek egemen üretim tarzına dönüşmüştür. Çarkta çömlek üretimi artık, ticaretinin arttığı, seri kitlesel üretim tarzıydı.

Uruk'tan Arslantepe'ye gelen çömlekçi çarkı, oradan da Anadolu'nun batısına ve Güney Kafkasya'ya (Transkafkasya) doğru hızla ilerledi. Bu dönemin Anadolu'da öncelikle, Güney Kafkasya 
istikametinde Erzurum Karaz kültüründe, batıya doğru ise öncelikle Güney ve Güney Doğu yerleşmelerinde çarklı çömlekçiliği izleyebiliyoruz. Truva, Akdeniz bölgesi batısında, Karataş-Semayük, Antalya kuzeyinde Bademağacı, yine Akdeniz bölgesinin doğusunda, Gözlükule, İç Anadolu'da Alişar, ilk çarklı çömlekçilik yerleşmeleridir. Troia II ve VI. tabadaki yerleşmelerin böyle bir aşağı kentte sahip olmasını I. evreye kadar indirgeyebiliriz. Bu evrede çömlekçi çarkı Marmara Bölgesi'ne henüz gelmemiştir (Harmankaya, t.y: 15).

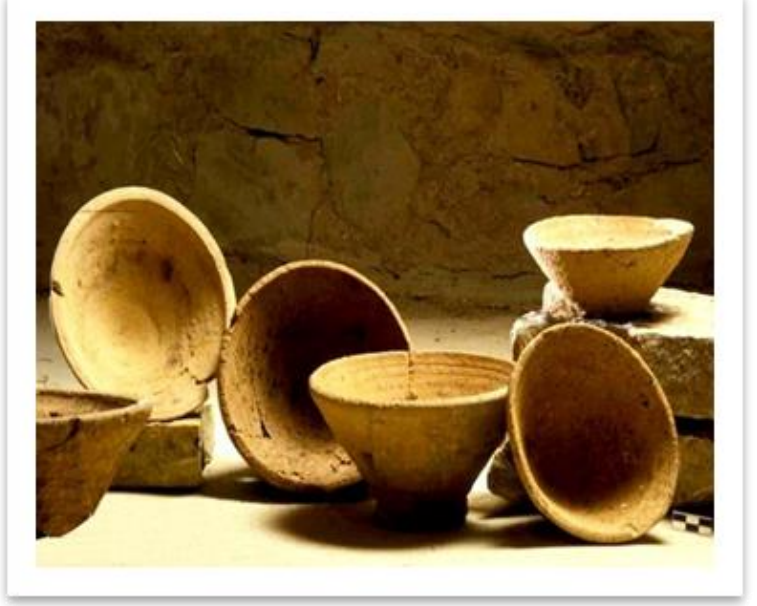

Görsel 9: Arslantepe Çarkta Yapılmış Çömlekler (Atlas Dergisi)

Çarkta çömlek kap üretiminin teknolojik gelişimi ile oluşan endüstriyel anlayış, kuşkusuz başka teknikleri de tetikledi. Madenleri kullanabilen insan bu dönemde pişmiş toprağı, metal şekillendirmede kullanmasını da öğrendi. Döküm yaparak madeni şekillendirebileceğini fark etti.

Döküm işi, kalıp gerektirir. Bir yanı düz bir eşya yapmak için kullanılan kalıp kolayca biçimlendirilebilir, kalıp kilden yapılır, istenilen biçime getirilir, içine eritilmiş maden dökülür. Oysa keskin bir kama yapmak ve her iki yanını kavisli biçimlendirmek çetindir. Böylesine bir alet için iki parçalı bir kalıp kullanılmalıdır, her iki parça da eş olmalı ve birbirine bağlanmalı ya da kenetlenmelidir. M.Ö. 3000 yıllarında, Mezopotamya'da çok ilginç bir buluş olan "cine perçine" yöntemi uygulanmaktaydı. İstenilen aletin modeli önceden mumdan yapılır, sonra üstüne kil kaplanır; kil ısıtıır, böylece çömlek olur, bu arada mum eriyip akar, bundan sonra içindeki boşluğa maden akıtılır, en sonunda kil kalıp kırılır, mum modelinin biçimindeki maden ortaya çıkar (Childe, 2006: 75-76). O devirde bu işlem, seramiğin gelişen endüstriyel üretime çok farklı ama ilginç bir girişiydi. Tuncun keşfi ve kullanımıyla 
her ne kadar seramiğin ikinci plana düştüğü söylense de pişmiş toprak Anadolu'da vazgeçilmezliğini sürdürüyordu.

Kalkolitik Çağın başlarında tüm Anadolu'da iklimin giderek normalleşmesi ve bunun sonucunda beliren bugünküne yakın coğrafi koşullar nüfusun artışına neden olmuştu. İnsanoğlu giderek daha fazla sayı ve türde mal üretmenin yollarını araştırmaya başlamıştı. Bu yeni dönem, önceki çağların tarım, dokumacılık, çömlekçilik vb. buluşlarına daha etkili silahların üretilmesini, daha ince süs eşyalarının yapılmasını olanaklı kılan bakır-arsen ya da bakır-kalay alaşımı yani tuncu eklemişti (Sevin, 1999: 94).

Tüm bu gelişimleri sağlayan sosyal zekâ ortamında, doğal olarak toplumsal yapı güçlenecek ve yönetim tarzları değişecekti. Köy toplulukları artık kentleşip yerel devletler halinde büyüyordu.

\section{BÖLGESEL DEVLETLER, KİL TABLETLER, ORTA TUNÇ ÇAĞI, ASUR TİCARET KOLONİLERİ (M.Ö. YAKLAŞIK 2000- 1650)}

M.Ö. 2. bin yılın eski evrelerinde Orta Anadolu'da bir düzineden fazla kent devleti ortaya çıkmıştır; günümüzde bunların konumları, bölgedeki en büyük höyükler olarak ayırt edilmektedir. Öncesi ve sonrasındaki dönemlerle karşılaştırıldığında, yabancı kültür öğelerinin bölgeye sızdığı ve gelişmiş yerel üslupların yaygınlaştığı, daha kentsel özellikli bir dönemin yaşandığını görmekteyiz. M.Ö. 2000-1650 yılları arasında ortaya çıkan çanak çömlek biçimleri ve maddi kültürün diğer özellikleri, Tunç Çağı'nın MÖ. 1200'den kısa bir süre sonrasındaki bitimine dek büyük bir kırılma olmadan etkili olmaya devam etmiştir (Sagona, 2009: 199). Bu dönemin önemli yerleşmeleri, Beycesultan, Konya Karahöyük, Kültepe, Acemhöyük, Alişar, Boğazköy gibi yerleşmelerdir.

Bu dönemden itibaren yazılı belgeler de ortaya çıkmaya başlar. Çivi yazılı kil tabletler, o günkü koşulların yazılı anlaşmaları, evrakları ve mektuplarıdır. Çanak çömleğin hammaddesi toprak ve kil bu uygar aşamada yine devrededir ve pişmiş toprak olarak yazılı belgelere dönüşmüştür. Bu yazılı belgeleri günümüze ulaştıran en önemli merkez Kültepe'dir. Zira Asurluları aynı zamanda Anadolu'da en önemli ticaret merkezi olma özelliğine sahip Kültepe aynı zamanda, bugüne en çok belge olarak buluntu veren yerleşmelerden biridir. 


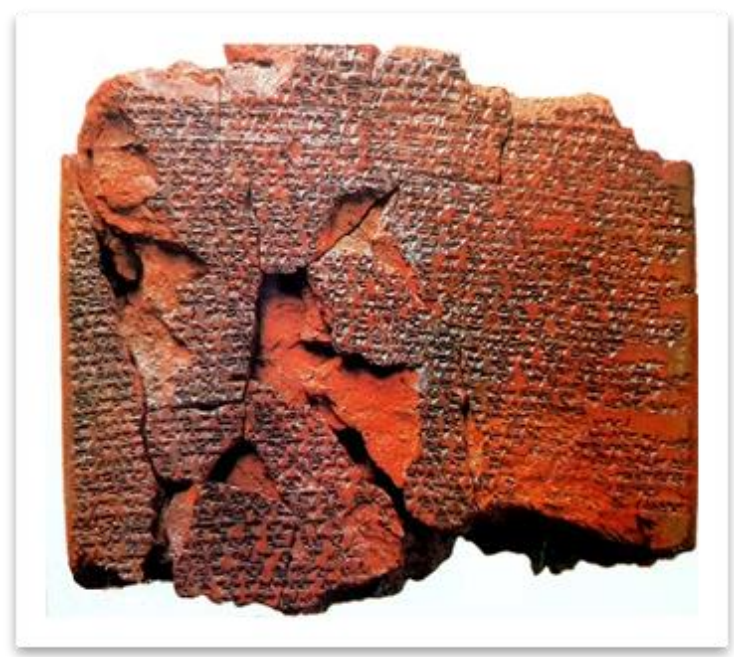

Görsel 10: Kil Tablet Üzerine Mısır-Hitit Barış Antlaşması (Akurgal, 1998:

166)

Kültepe'de açığa çıkarılan tabletler ve arkeolojik bulguların tümünün yayımlanması gecikmeli olarak ilerlese de genel tablo çok nettir. Karuma ait kazılardan elde edilen 20.000 civarında kil tablet bilinmektedir. Metinler kil tablet yerine daha çabuk bozulabilen bir madde üzerine yazılmış olsaydı, günümüze kadar ulaşamayacak olan bu tabletler olmadan Asurluların Kültepe'de yaşamış olduklarına dair çok az kanıtımız olurdu (Sagona, 2009: 203). Pişmiş toprak yani seramik parçalansa da yok edilemeyen bir malzemedir. Dolayısıyla, insanın uygarlık yolundaki serüveninde seramiğin önemli rolü hala devam ediyordu. Pişmiş toprak bir yandan ticari ve kamusal alanlarda defter olarak kaydedici işlev görürken, diğer yandan da estetik görselliğini daha da geliştiriyordu. Kırmızı, siyah ve beyaz renkler kullanılarak yapılmış geometrik desenli çanak çömlekler, dönemi devam ederken ortadan kalmasına rağmen bugüne ulaşan en iyi çanak çömlek örneklerindendir.

\section{HİTİT EGEMENLİĞí, RİTONLAR, GAGA AĞIZLI TESTİLER (M.Ö. 1650-1200)}

Anadolu'nun kültür tabaklanmasında çok önemli yer tutan Hititler, devlet yapılanması, çok tanrılı dinleri, mimari sanat gibi birçok alanda Anadolu kültür geçmişine damgasını vurmuştur. Orta Anadolu'da hemen hemen tüm Eski Tunç Devri yerleşmelerinin üzerinde bir Hitit yerleşmesi bulunmuştur. Hititlerin, binlerce kil tablet üzerindeki yazışmalarından, ticaret belgelerinden, kaya kabartmalarındaki betimlemeler gibi verilerinden de anlaşılacağı üzere, batılı bilim insanları da dahil, Hititlerin Son Tunç Çağı'nda çok önemli 
bir güç olduğu genel kabul görmüştür. Kaldı ki bu veriler sadece kamusal, politik anlatımda değil, aynı zamanda dönemin ritüellerini, edebi düşüncelerini de anlatan entelektüel verilerdi.

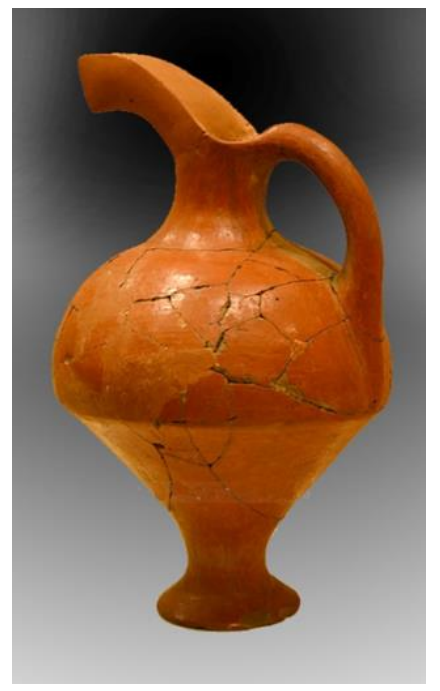

Görsel 11: Eski Hitit Dönemine Ait Gaga Ağızıı Testi (Akyıldız, 1997: 37)

Asur Ticaret Kolonileri Çağında ticaretin esasını oluşturan hammadde alışverişi Hitit döneminde de devam eder. M.Ö. 2. binde Anadolu'da bulunmayan kalayın Anadolu'ya Orta Asya'dan Mezopotamya ve Suriye aracılığı ile gelmiştir. Bu dönemde kalay külçe halinde bulunmasa da dönemin en yaygın üretilen madeni tunç için gerekli bir madendi (Kozal, 2010: 14).

Madenin, yoğun ticaretinin yapılarak döküm ve işleme teknolojisinin gelişmesiyle adını verdiği Tunç Çağında bu denli önemli olması, her ne kadar pişmiş toprak kap ve gereç gereksinimini ikinci plana itmiş görünse de Hitit kültürü, değişik form ve bezekleriyle çok farklı bir seramik anlayışı üretmiştir. Dönemin seramikleri, temel intiyaç malları olmaktan ziyade estetiğe ve sanata yönelmiştir. Doğrudan işlevsel kaplarda ve sanatsal kaplarda genellikle bezemeler, açkılı, kısmi kabartmalı, frizli, metoplu, panellidir. Hayvan baş ve gövdeleri betimli riton [rhyton] kaplar, gaga ağızlı ince uzun ayaklı testiler en güzel Hitit seramiği örnekleridir. Ayrıca seramik mühürlerdeki radyal düzenlemeli özenli betimler de dikkat çekicidir. Bu pişmiş toprak kaplar genelde bezek ve formlarıla stilize edilmek suretiyle kültsel mesajlar vererek ritüellerde kullanılmıştır 


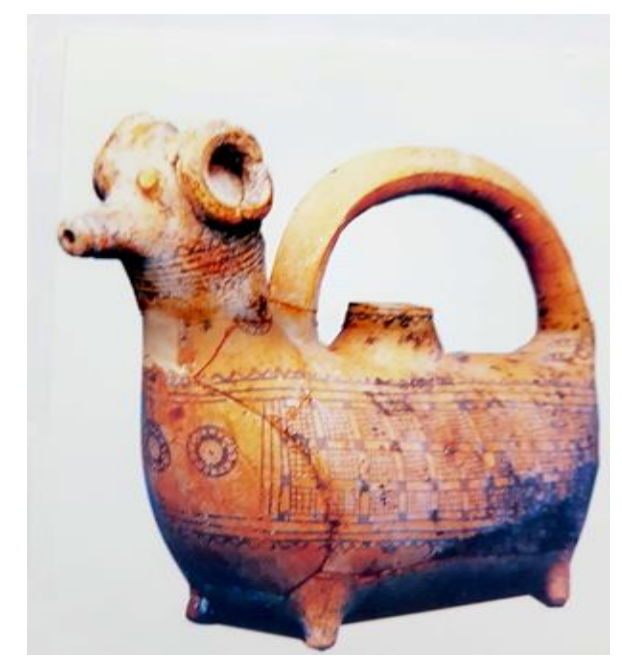

Görsel 12: Riton Vazo (Müze Sitesi)

\section{HİTİT SONRASI BEYLİKLER (KALINTILAR), KARANLIK ÇAĞ, DEMİR ÇAĞI (M.Ö. YAKLAŞIK 1200-600)}

Yakındoğu'nun Tunç Çağı, M.Ö. 1200 dolaylarında Karanlık Çağ içine girilmesiyle sona erdi. Yalnızca tek bir devlette değil, fakat uygar dünyanın büyük bir bölümü üzerinde tarih kesintiye uğramış görünür; yazılı kaynaklar kurumuş, arkeolojik belgeler az ve kolay tarihlendirilemeyecek durumdadır (Chide, 2018: 232). Ekrem Akurgal Karanlık Çağı, Troia (M.Ö. 1050-700), Orta Anadolu (1200-750), Batı Anadolu (1200-1050) Karanlık Çağları olmak üzere, yerleşmelere ve bölgelere göre farklı tarihlendirmektedir. Demir Çağının önemli uygarlıkları, Geç Hitit Beylikleri, Urartu, Lydia, Karia, Frig ve Lykia Medeniyetleridir. Hititlerin M.Ö. 1200'lerde ortadan kalkmasını takiben, Güneydoğuya çekilen Hitit kalıntıları olan beyliklerin Hitit sanatı uzantısı olarak dikkat çeken eserleri, kaya kabartmalarıdır ve bu kabartmalardaki insan ve hayvan betimlerindeki değişikliklerdir.

Urartu'larda çanak çömlekçilik çok gelişmişti. Bu dalda daha çok madenciliğin etkisi söz konusuydu. Çömlekçi atölyelerinde üretilen kırmızı renkli ve parlak görünümlü lüks mallar bakır, tunç gibi madeni kapların taklidiydi (Sevin, 1999: 187). Urartu'da karakteristik kaplar, frizli, panelli olarak bezenmiş tek kulplu, karnı geniş, yonca ağızlı kaplardır. Urartu'da daha ziyade metal işleme sanatı ön plandadır. Bu yüzden en iyi kaliteli seramik kaplar bile metal taklididir.

Frigler Troia VIIb'nin tahrip edilmesinden sonra M.Ö. 1190 sıralarında Anadolu'ya gelen Balkan kökenli boylardan biridir (Akurgal, 
1998: 265) Bu dönemin maden işlemeciliği sanatı hakimiyetine rağmen Friglerden, form ve bezekleriyle özenli çok güzel kap örnekleri günümüze ulaşmıştır. Urartu'da olduğu gibi Friglerde de çanak çömlek yapımı çok iyi bir seviyede olmasına karşın, yine maden işlemeciliğinin etkisi altıdaydı.

Frig coğrafyasında, Kızılırmak'ın doğu ve batısındaki farklı etnik öğelere göre farklı teknikte üretimde bulunan atölyeler bulunmaktaydı. Batı kısmında Makedonya'dan gelmiş olanlar daha çok metalik gri ve siyah renkli kaplar kullanıyorlardı, doğuda ise çok renkli kaplar hakimdi. Çoğu kez madeni kapları taklit eden Frig çömlekçileri hayvan biçimli vazoların yapımında da büyük bir başarı sağlamışlardır (Sevin, 1999: 206). Frig çömleklerinde, geometrik bezeklerle konturlanmış stilize hayvan desenleri hakimdir.

Kimmerlerin saldırıları ve talanları sonucunda M.Ö. 7. yüzyılın ikinci dörtlüğünde Orta Anadolu'nun egemenliği Frigyalılardan Lidyalılara geçti (Akurgal, 1998: 283) 1. bin yılda Anadolu'nun dikkat çekici halklarından biri de Lidyalılardır. Batı Anadolu'da Gediz ve Küçük Menderes yörelerinde oturan bu halkın ne zaman ve nereden geldikleri konusu açık değildir (Sevin, 1999: 208). Madeni sikkenin icadıyla tanınan Lidyalılar, Seramik, müzik, heykel ve kabartma sanatlarıyla dönemlerine değer katmışlardır. Lidya seramikleri, özgün ve Helen etkisi altında olmak üzere iki türdür. Lidya seramiğinin bir özelliği dalgalı mermer ve cam kapları anımsatan çizgi ögeleriyle bezeli oluşudur. Kapların hamuru ve fonu beyaz, sarı ya da turuncu rengiydi (Akurgal, 1998: 284). Karialılarda geometrik desenli örneklerde genellikle Ege Akdeniz seramiği karakteristiği baskın olup, amforalar hariç çoğunlukla kaplar geniş karınlı, tek kulplu, bezekler ise panelli konturlu ve frizlidir. Likya'daki seramik buluntuların özgün olup olmadığı tartışmalı olup gereksinimleri olan çanak çömleğin de Helen ithalatı olduğu söylenmektedir.

Anadolu'da binlerce yıllık bir kültürün birikimi kuşkusuz Helenistik ve Roma Dönemlerine de yansıyacaktı. Nitekim bu birikimin tortusu olan bu kültürler de gerek mimaride gerekse sanatta güzel eserlerini Anadolu'ya bırakmıştır. Seramik açısından bakacak olursak özellikle 
Geç Helenistik, Erken Roma Dönemlerinin Terra Sigillata çanak çömlekleri de en güzel örneklerini Anadolu'da vermiştir.

\section{ANADOLU'DA GÜNÜMÜZ SERAMİĞİ}

Binlerce yıllık pişmiş toprak geleneğinin arkeolojik kapsamda verilerinin günümüze kadar ulaşıp bilimsel olarak disiplinler arası çalışmalara hizmet ettiği, teknolojik gelişim açısından uzay aracı başlıklarına kadar uzandığı bir gerçektir. Anadolu coğrafyasını göz önüne alarak sosyo-kültürel olarak baktığımızda da tüm çağların dolu dolu yaşandığı bu topraklarda hiç kuşku yok ki çömlekçilik, çok önemli izler bırakmıştır.

Anadolu'da kadının başlattığı çömlekçiliğe, çarklı çömlekçilikten sonra erkeğin de katıldığını görüyoruz. Etnoarkeolojik kapsamda bu kültür, Anadolu'da bugün direnerek de olsa yaşamaya/yaşatılmaya devam etmektedir. Anadolu'da ilkel milsiz çark örneklerinden, kısa ve uzun milli çarka kadar, hatta çarksız, Neolitik Dönem benzeri aynı üslupla hala çömlek üretilmektedir. Dolayısıyla binlerce yıllık bir kültürün eylemsel olarak biçimselliğini bozmadan yaşamaya devam etmesi kültür değerleri kapsamında çok önemlidir. Cumhuriyetin öncü bilim insanlarından H. Z. Koşay, Ş. A. Kansu, A. R. Yalgın gibi isimler, önderliğini yaptığı etnografik çalışmalarında "Anadolu'da Yaşamakta Olan İlkel Çömlekçilik" alanına önemle yer vermişlerdir. Zamanın Dil Tarih Coğrafya Fakültesi Arkeoloji doçenti Feridun Kurt Andolsun 1938'de,

"Çömlek sanatının her münferit eşyası, her tek numunesi, sanğatkar insan ellerinden dökülmüş bir eserdir. (...) Çömlek ve çanak sağnatının veya sağnatlarının tecelliyatı, üzerinde işleyebileceğimiz, pek zengin bir malzeme kaynağıdır. Ve kırık dökük parçalar halinde dahi olsa, yine her parça orjinal bir sağnat işi olduğundan, çömlekçiliğin, bize tarihten, gelmiş-yaşamış-vegöçmüşten haber veren şehadeti, belki sair hiçbir insan vesikasının mümkün kılamadığı, daha şümullü ve çok daha isabetli hüküm jenarilizasyon formülasiyonlarını temin eder" (Andolsun, 1938: 9).

diyerek Cumhuriyetin ilk yıllarında pişmiş toprağın önemine vurgu yapmıştır. 


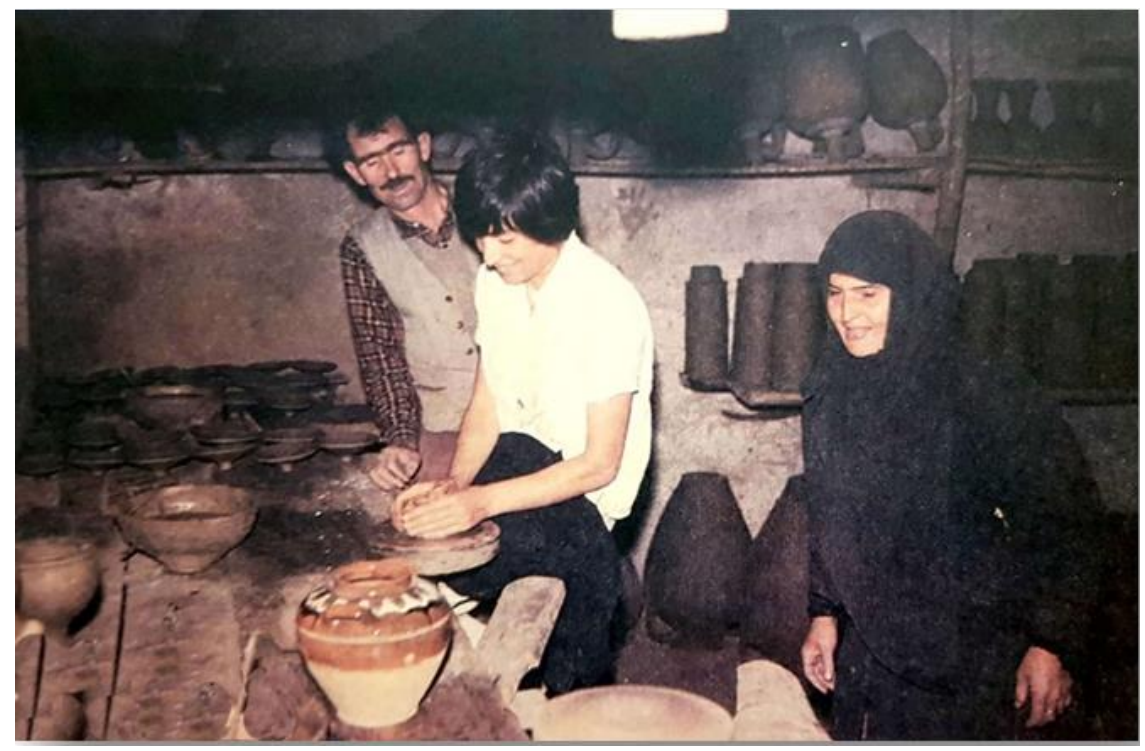

Görsel 13: Profesör Güngör Güner'in Saha Araştırması, Mustafa Kemal Paşa Çömlekçileri İle (Güner, 1988: 79)

Diğer taraftan, çağdaş sanat kapsamında Sadi Diren, Füreya Koral gibi sanatçıların öncüllüğünü yaptığı seramik sanatı da gerek akademik gerekse modern sanat ortamlarında her geçen gün kendini uluslararası düzeyde geliştirmektedir. Ayrıca seramiğin vitrifiye mutfak banyo gereçlerinden, savunma sanayiindeki zırhlı araçlara, uzay aracı başlıklarına kadar ulaştığı teknoloji ortamında "Üniversite" ve "Sanayi" iş birliği ile üretsel anlamda seramik sektörünün çok daha iyi yerlere ulaşacağı umut edilmektedir.

\section{SONUÇ VE DEĞERLENDİRME}

İnsanoğlu, öncelikle birinci basamak gereksinimlerini karşılayarak yaşantısını devam ettirebilmek için doğanın güçlerine karşı birlikte hareket etme zorunluluğu duymuş ve güçlerini birleştirerek bir arada olmaları onları birtakım yasalara zorlamıştır. Uygarlıklar, sosyal bir varlık olan insanın bireysel zekâsının önce ait olduğu topluluklarda sonra da toplumlarda yarattığı artı değerle oluşan kolektif akılla meydana gelmiştir. Bu nedenle var oluşundan itibaren öncelikle yaşamsal gereksinimlerini karşılayacak gereçleri keşfetmiş, sonra da tutunabildiği yaşamı anlamaya çalışarak kendini geliştirmiştir.

Genelde tanımı yapılan kültür için, en yalın haliyle doğal yasalara bağlı olarak tarihi ve toplumsal gelişme süreci içinde yaratılan maddi ve manevi değerlerin tümüdür diyebiliriz. Toplumsal gelişmelerin ve 
kültürel değişimlerin birbirlerine, düzgün değişen pozitif yönde bir ivme ile ileri doğru etkileri kaçınılmazdır. Kültürü de içinde barındıracak şekilde toplumsal değişimi ise, toplum yapısının ve bu yapının toplumsal ilişkiler ağının, kurallarının ve bu ilişkileri ve kuralları belirleyen toplumsal kurumların değişimi olarak tanımlayabiliriz.

Bu makalede, çağlar boyu alet yapımından hareketle; pişmiş toprak kullanımının, yarattığı kültürel, teknolojik, endüstriyel ve sanatsal değerleriyle günümüze taşıdığı önem ana eksene alınarak anlatılmaya çalışılmıştır. Pişmiş toprak, yok edilemeyen bir malzeme olması nedeniyle kuşkusuz arkeoloji biliminde özellikle filolojik verileri olmayan dönemlerden itibaren çok önemli bir bilgi kaynağıdır. Kırık dökük çömlek parçaları bile binlerce yıllık geçmişimizden günümüze yazılan mektuplar gibidir. Bu veriler, günümüz doğa bilimlerine, arkeolojik, antropolojik, sosyolojik vb. alanlara bilgi aktarır, örneğin; çömleklerde bulunan kömürleşmiş tahıllar o dönemin üretimini, o döneme ilişkin tarımı ve ayrıca o dönemdeki alanın florasını, iklimini anlatan kanıtları oluşturur.

Değişimin evreni ve hangi boyuttaki değişmelerin toplumsal değişim olarak adlandırılacağı konusu bilim insanlarınca hep tartışıla gelmiştir. Toplum her daim devinim ve değişim hâlinde yüksek dinamikte bir oluşumdur. Bu nedenle, hangi düzeydeki değişimlerin göz önüne alınacağı konusunda, değişenin ve değiştirenin çarpan etkileri öne çıkarılarak ortak kabul alanında geçmişin çağ bölüşümü yapılmıştır. Buna göre konumuzla ilgili olarak, Neolitik Çağ bir tarım devrimidir, ardından bu evreyi ikiye bölen çanak çömlekli dönemdir. Yine aynı şekilde çarklı çömlekçilik ve madenin işlenmesi endüstrinin temellerini oluşturan büyük atılımlardır. Dolayısıyla da günümüzde gelişimi tüm safhalarıyla anlayabilmek, bilimsel değerlendirmelerini yapabilmek çok önemlidir. Diğer taraftan bu kavrayış, kültür ve sanat değerleri olarak da ait olduğu topluma mutlaka ciddi kazanımlar sağlayacaktır.

Pişmiş toprak ekseninde yapılan gözlemlerde; teknolojik olarak dünyadaki çağdaşlarına koşut ilerlemeler ülkemizde de sektörel kapsamda takip edilmektedir. Kültürel boyutta ise, dünyanın pek çok ülkesinde Anadolu'dan çok daha geç evrelerde çömlekçilik yapılmasına karşın bu ülkelerde çömlekçilik, "Somut Olmayan Kültürel Miras" 
listelerine kabul ettirilmiştir. Ancak ne var ki Neolitik'ten bugüne Anadolu'da yaklaşık 9000 yıllık geçmişi olan çömlekçilik geleneği, üstelik henüz yok olmadan direnerek de olsa devam etmesine rağmen birçok ilimizin SOKÜM envanterlerinde yer almamaktadır. Çömlekçiliğin ve çarklı çömlekçiliğin Anadolu'nun çoğu yöresinde (bu alanların aynı zamanda arkeolojik geçmişi yoğun bölgeler olması dikkat çekicidir), arkeolojik kapsamda, binlerce yıldır benzer tarzda üretiminin, eylemsel olarak günümüze kadar taşınıp sürdürülmesi sosyo-kültürel açıdan önemlidir.

Ülkemizde 19. yüzyılda Fethi Ahmet Paşa ve Osman Hamdi Bey ile başlayan müzecilik ve arkeoloji serüveni, elbette çağdaş ve aydın bir bakışla Mustafa Kemal Atatürk'ün de öncelikleri arasında olacaktı. Nitekim daha Cumhuriyet kurulmadan bu toprakların geçmişine de sahip çıkmanın önemini bilen Atatürk, TBMM'nin açılışının hemen arkasından 9 Mayıs 1920'de göreve başlayan ilk hükümetin yapacağı işler arasında eski eserlerin derlenmesi ve yeni müzeler kurulması talimatını verir. Bu amaçla Maarif Vekâletine bağlı, şimdi "Kültür Varlıkları ve Müzeler Genel Müdürlüğü" olan "Eski Eserler Müdürlüğü (Asar-ı Atika Müdürlüğü)" kurulur. Büyük Önderi kültür varlıklarımız için yaptığı çok değerli katkılarla anarken arkeoloji ile ilgili bir önemli olay da meşhur "Konya Telgrafı"dır. Semavi Eyice'nin Türk Kültür Tarihinin en önemli hadiselerinden olarak gördüğü, Atatürk'ün tarih ve tarihi eserler hakkında Maarif Vekâletine yolladığı ünlü Konya telgrafında, telgrafın birinci maddesinde Atatürk'e ait şu ifadeler yer alıyordu:

"Gezdiğim gördüğüm yerlerde bazı arkeolojik kazıların yabancılar tarafından yapılmakta olduğunu gördüm, bundan böyle bunları Türk gençleri yapsın. Şu hâlde Milli Eğitim Bakanlığı bazı Türk gençlerini Avrupa'ya göndersin, bunlar arkeoloji eğitimi görsünler, kazıları onlar yapsınlar."

\footnotetext{
* Yasemin Akçaoğlu'nun 2005'te hazırladığı "Türk Sanatına ve Tarihine Katkılarıyla Semavi Eyice" başlıklı teze göre, Eyice'nin hayatında Mustafa Kemal Atatürk'ün tarih ve tarihi eserler hakkında yolladığı telgraf kırılma noktası oluşturdu. Atatürk imzalı telgrafın ilk maddesinde "Gezdiğim gördüğüm yerlerde bazı arkeolojik kazıların yabancılar tarafından yapılmakta olduğunu gördüm. Bundan böyle bunları Türk gençleri yapsın. Şu halde Milli Eğitim Bakanlı̆̆ı bazı Türk gençlerini Avrupa'ya göndersin, bunlar arkeoloji eğitimi görsün, kazıları onlar yapsın." ifadeleri, ikinci maddesinde ise "Gezdiğim gördüğüm yerlerde Türk eserlerinin harap durumda olduğunu gördüm. Bilhassa Konya'dakiler perişan bir halde... Bunların restorasyonu için Vakıflar Idaresine gerekli talimatın verilmesi fakat ezeli emirde bunlar asker işgali
} 
Atatürk elbette kültür varlıklarının öneminin yanı sıra buna bağlı başka şeyleri de göz önüne almıştı.

Türkiye bir arkeoloji zengini ülkedir. Hemen her döneme ait açılmış açılmamış yüzlerce belki binlerce höyük bu kültür varlığının çok bariz örneğidir. Arkeoloji bilim insanlarınca, 5-10 tabakalı ören yerinin tam açılmasının 100-300 yıl sürebileceği söylenmektedir. Bu durumda, yüzlerce ören yerini göz önüne alırsak; bunlar da iyi korunup kültür politikalarında hak ettiği yeri alırsa, ülkemizin çok daha uzun asırlar kültürel anlamda bir cazibe merkezi olması kaçınılmazdır.

\section{KAYNAKÇA}

Akurgal, E. (1998). Anadolu Kültür Tarihi. Ankara: TÜBİTAK Popüler Bilim Kitapları.

Akyıldız, E. (1997). Taş Çağından Osmanlı'ya Anadolu. İstanbul: Milliyet Yayınları.

Andolsun, F. K. (1938). Arkeolojik Tetkiklerde Çömlek Sağnatının Ehemmiyeti. Ankara: Halkevi.

Avcl, H. E. (2013). Uygarlıklar Tarihi. İstanbul: İstanbul Üniversitesi Yayınları.

Braidwood, R. J. (1995). Tarih Öncesi İnsan. (Çev.). Altınok B. İstanbul: Arkeoloji ve Sanat Yayınları.

Childe, G. (2006). Kendini Yaratan İnsan. (Çev.) Ofluğlu, F. İstanbul: Varlık Yayınları.

Childe, G. (2010). Doğunun Prehistoryası. (Çev.). Kansu, Ş. A. İstanbul: Türk Tarih Kurumu Matbaası.

Childe, G. (2018). Tarihte Neler Oldu. (Çev.). Şenel A. İstanbul: Kırmızı Yayınları.

Duru, R. (1996). Kuruçay Höyük II. Ankara: Türk Tarih Kurumu Basımevi.

Güner, G. (1988). Anadolu'da Yaşamakta Olan İlkel Çömlekçilik. İstanbul: Akbank Ak Yayınları Kültür Serisi.

Kozal, E. (2010). Son Tunç Çağı'nda Anadolu ve Komşuları. İstanbul: Arkeoatlas Yaşayan Geçmişim Dergisi 7(1). 
Kulaçoğlu, B. (1992). Tanrılar ve Tanrıçalar. Ankara: Kültür Bakanlığı Anadolu Medeniyetleri Müzesi Ana Basım.

Melaart, J. (1998). Yakındoğu'nun En Eski Uygarlıkları. İstanbul: Arkeoloji ve Sanat Yayınları.

Ökse, A. T. (2015). Arkeolojik Çalışmalarda Seramik Değerlendirme Yöntemleri. İstanbul: Arkeoloji ve Sanat Yayınları.

Roller, L. E. (2013). Ana Tanrıça'nın İzinde. (Çev.). Avunç, B. İstanbul: Alfa Basım Yayın.

Sevin, V. (1999). Anadolu Arkeolojisi. İstanbul: DER Yayınları.

Sagona, A. \& Zimansky, P. (2009). Arkeolojik Veriler Işığında Türkiye'nin En Eski Kültürleri. (Çev.). Kurulu, Başgelen vd. İstanbul: Arkeoloji ve Sanat Yayınları.

Şenel, A. (1982). İlkel Topluluktan Uygar Topluma. (Çev.). Kurulu, Başgelen vd. Ankara: Ankara Üniversitesi Siyasal Bilgiler Fakültesi Yayınları.

Uhlig, H. (2007). Avrupanın Anası Anadolu. (Çev.). Bayer, Y. İstanbul: Telos Yayıncilık.

\section{İNTERNET KAYNAKLARI}

Harmankaya S. (2019). Türkiye İlk Tunç Çağı Araştırmaları Üzerine Bir Değerlendirme. Erişim Adresi: www.tayproject.org. Erişim Tarihi: 19.06.2019.

\section{GÖRSEL KAYNAKLAR}

[Görsel 1, 4]. Sagona, A. \& Zimansky, P. (2009). Arkeolojik Veriler Işığında Türkiye'nin En Eski Kültürleri. (Çev.). Kurulu, Başgelen vd. İstanbul: Arkeoloji ve Sanat Yayınları.

[Görsel 2, 3, 5]. Kulaçoğlu, B. (1992). Tanrılar ve Tanrıçalar. Ankara: Kültür Bakanlığı Anadolu Medeniyetleri Müzesi Ana Basım A. Ş.

[Görsel 6, 7, 8]. Duru, R. (1996). Kuruçay Höyük II. Ankara: Türk Tarih Kurumu Basımevi.

[Görsel 9]. Arslantepe Çömlekleri. Erişim Adresi: atlasdergisi:com/kesfed/arkeoloji/4536html.

[Görsel 10]. Akurgal, E. (1998). Anadolu Kültür Tarihi. Ankara: TÜBİTAK Popüler Bilim Kitapları.

[Görsel 11]. Akyıldız, E. (1997). Taş Çağından Osmanlı'ya Anadolu. İstanbul: Milliyet Yayınları. 
[Görsel 12]. Riton Vazo. Erişim Adresi: https//muze/gov.tr.muze/detay.

[Görsel 13]. Profesör Güngör Güner'in Saha Araştırması. Güner, G. (1988). Anadolu'da Yaşamakta Olan İlkel Çömlekçilik. İstanbul: Akbank Ak Yayınları Kültür Serisi. 